\title{
Biodiversity, ecosystems and coastal zone management: linking science and policy
}

\author{
Editors: D. M. Paterson, N. D. Hanley, K. Black, E. C. Defew, M. Solan
}

\section{CONTENTS}

Paterson DM, Hanley ND, Black K, Defew EC, Solan M

Science and policy mismatch in coastal zone ecosystem management ....

Ruttenberg BI, Granek EF

Bridging the marine-terrestrial disconnect to improve marine coastal zone science and management

Holt AR, Godbold JA, White PCL, Slater AM, Pereira EG, Solan M

Mismatches between legislative frameworks and benefits restrict the implementation of the Ecosystem Approach in coastal environments

Gedan KB, Altieri AH, Bertness MD

Uncertain future of New England salt marshes
Ruiz-Frau A, Edwards-Jones G, Kaiser MJ

Mapping stakeholder values for coastal zone

management

Mora C, Sale PF

Ongoing global biodiversity loss and the need to move beyond protected areas: a review of the technical and practical shortcomings of protected areas on land and sea ................................. 251-266

Cook ASCP, Parsons M, Mitchell I, Robinson RA

Reconciling policy with ecological requirements in biodiversity monitoring

Nobre AM

Scientific approaches to address challenges in coastal management ..................................... 279-289

Townsend M, Thrush SF, Carbines MJ

Simplifying the complex: an 'Ecosystem Principles Approach' to goods and services management in marine coastal ecosystems

\section{INTRODUCTION}

\section{Science and policy mismatch in coastal zone ecosystem management}

\author{
D. M. Paterson ${ }^{1,2}$, N. D. Hanley ${ }^{1,3}$, K. Black ${ }^{1,4}$, E. C. Defew ${ }^{1,2, *}$, M. Solan ${ }^{1,5}$ \\ ${ }^{1}$ Marine Alliance for Science and Technology for Scotland, MASTS, SOI, East Sands, St Andrews, Fyfe KY16 8LB, UK \\ ${ }^{2}$ Scottish Oceans Institute, East Sands, St Andrews, Fife KY16 8LB, UK \\ ${ }^{3}$ Management School, University of Stirling, Stirling FK9 4LA, UK \\ ${ }^{4}$ Scottish Marine Institute, Oban, Argyll PA37 1QA, UK \\ ${ }^{5}$ Oceanlab, University of Aberdeen, Main Street, Newburgh, Aberdeenshire AB41 6AA, UK
}

\begin{abstract}
Coastal zone ecosystems and the goods and services they provide are under increasing pressure from anthropogenic impacts. Climate change and demographic effects are particularly relevant, and it is critical to establish proper control systems (policies) to protect and conserve the wideranging benefits that these systems provide. The concept of 'holistic assessment', the Ecosystem Approach, is now being widely promoted, but the relationship between the science supporting this policy and the development of the policy itself is not always well-coordinated. This Theme Section discusses applications of science to coastal zone management and provides a critique of some approaches.
\end{abstract}

KEY WORDS: Coastal zone management $\cdot$ Marine policy $\cdot$ Ecosystem Approach $\cdot$ Science policy 
The need for improved Coastal Zone Management (CZM) results from a strong societal requirement to control the behaviour of individuals and organisations that affect and exploit coastal marine ecosystems and their goods and services. This Theme Section, sponsored by the Marine Alliance for Science and Technology for Scotland, addresses some of the issues that arise from the often unequal development of science and science policy for coastal marine systems. The recognition of environmental impact can be slow and difficult to determine due to the complexities (and costs) involved in sampling and surveying marine systems, and the development of relevant policy for marine systems in general has lagged behind work on terrestrial habitats (Ruttenberg \& Granek 2011, this Theme Section). A wide variety of stakeholders and users may need to be involved in policy decisions, since the advective movement of water and waterborne materials, including the biota, can spread problems rapidly among legislative control areas. This inherent complexity is set against the background of increasing environmental pressure on coastal systems that arises from demographic pressures, increased resource exploitation, and anthropogenic drivers such as pollution and global climate change. There is widespread recognition by local groups, national governments and international bodies that the delivery of benefits and services to society from coastal systems is under threat, and that the imbalance of knowledge between terrestrial and marine systems must be addressed. The concept of holistic system management, the Ecosystem Approach (EA), is gaining prominence for CZM. EA aims to enhance human well-being within a linked social and ecological system, based on principles of sustainable development. Hence the EA must be supported by improved description and a better functional understanding of coastal ecosystems (Holt et al. 2011, this Theme Section), which recognises that simple linear relationships between cause and effect are rare and that drivers of change may interact and vary in their effect depending on contextual circumstances. There is an urgent need to assess, provide and assure the science that is required to support policy and provide mechanisms to assess the outcome of different approaches. Many coastal systems are now being measurably affected by multiple stressors that reduce system resilience and enhance system decline: these present difficult management problems and uncertain futures (Gedan et al. 2011, this Theme Section). The coastal zone is exploited by many users, often with conflicting requirements, which makes the involvement of the widest possible community essen- tial in the development of sensible management plans (Ruiz-Frau et al. 2011, this Theme Section). There is a difficulty in assimilating the required scientific data, and presenting this information in a manner suited to policy requirements. There is also the potential that policy development outstrips the ability of science to deliver the required fundamental basis for management decisions. Thus, in the context of marine ecosystem management, it is important to continually assess the data available and develop management approaches (Mora \& Sale 2011, this Theme Section), aiming to translate research capability into policy as efficiently as possible (Cook et al. 2011, this Theme Section). In conjunction with the science required to provide information on the current status of ecosystems, there is also a need to interpret potential consequences of human activity and to develop methods of predicting how ecosystems and their associated biodiversity will respond in the future (Nobre et al. 2011, Townsend et al. 2011, both in this Theme Section). This on-going work is of increasing importance, as the impact of climate change and demographic pressures increasingly reduce the functionality of coastal systems. This Theme Section addresses modern approaches and critiques of CZM methodology.

\section{LITERATURE CITED}

Cook ASCP, Parsons M, Mitchell I, Robinson RA (2011) Reconciling policy with ecological requirements in biodiversity monitoring. Mar Ecol Prog Ser 434:267-277

Gedan KB, Altieri AH, Bertness MD (2011) Uncertain future of New England salt marshes. Mar Ecol Prog Ser 434: 229-237

Holt AR, Godbold JA, White PCL, Slater AM, Pereira EG, Solan M (2011) Mismatches between legislative frameworks and benefits restrict the implementation of the Ecosystem Approach in coastal environments. Mar Ecol Prog Ser 434:213-228

Mora C, Sale PF (2011) Ongoing global biodiversity loss and the need to move beyond protected areas: a review of the technical and practical shortcomings of protected areas on land and sea. Mar Ecol Prog Ser 434:251-266

Nobre AM (2011) Scientific approaches to address challenges in coastal management. Mar Ecol Prog Ser 434:279-289

Ruiz-Frau A, Edwards-Jones G, Kaiser MJ (2011) Mapping stakeholder values for coastal zone management. Mar Ecol Prog Ser 434:239-249

Ruttenberg BI, Granek EF (2011) Bridging the marine-terrestrial disconnect to improve marine coastal zone science and management. Mar Ecol Prog Ser 434:203-212

Townsend M, Thrush SF, Carbines MJ (2011) Simplifying the complex: an 'Ecolsystem Principles Approach' to goods and services management in marine coastal ecosystems. Mar Ecol Prog Ser 434:291-301 